\title{
Nature of glycosylphosphatidylinositols produced by mouse embryonic stem cells
}

\author{
L. R. Quinlan and M. T. Kane* \\ Department of Physiology, National University of Ireland, Galway, University Road, \\ Galway, Ireland
}

Incorporation of $\left[{ }^{3} \mathrm{H}\right]$ inositol into mouse embryonic stem cells of the CCE cell line leads to the labelling of the three common phosphoinositides, phosphatidylinositol, phosphatidylinositol 4-phosphate and phosphatidylinositol 4,5-bisphosphate, and a fourth unknown lipid (lipid X). Incubation with $\left[{ }^{3} \mathrm{H}\right]$ glucosamine results in the labelling of lipid $X$ and at least one other lipid that co-migrates with phosphatidylinositol (lipid Y), indicating that both of these lipids are putative glycosylphosphatidylinositols. In this study, the incorporation of other possible glycosylphosphatidylinositol precursors, ethanolamine, mannose and galactose, into lipids $X$ and $Y$ was examined. Galactose was incorporated into lipids $X$ and $Y$, and ethanolamine and mannose into lipid $Y$ only. Inhibitors of glycosylphosphatidylinositol biosynthesis pathways, mannosamine and 2-fluoro-2-deoxyglucose, both significantly inhibited ethanolamine incorporation into lipid Y. A high glucose concentration $\left(25 \mathrm{mmol} \mathrm{I}^{-1}\right)$ abolished the action of both inhibitors. Phospholipase $\mathbf{C}$ treatment of embryonic stem cells that had been labelled in culture with $\left[{ }^{3} \mathrm{H}\right]$ ethanolamine caused a large release of ethanolamine label into the incubation medium and markedly decreased the amount of ethanolamine-labelled lipid $Y$ remaining in the cell membranes. These effects were almost totally abolished by incubation with mannosamine before ethanolamine labelling. These studies strongly indicate that lipid $Y$ is a member of the protein anchor class of glycosylphosphatidylinositol, whereas lipid $\mathrm{X}$ is a member of the signal transduction inositol phosphoglycan class of glycosylphosphatidylinositol.

\section{Introduction}

There is increasing research interest in the role of inositolcontaining compounds in preimplantation embryo development. Inositol is essential for continued cell proliferation and growth of rabbit blastocysts (Fahy and Kane, 1992) and it also stimulates hatching of hamster blastocysts (Kane and Bavister, 1988). A major role of inositol is as part of the phosphatidylinositol (Ptdlns) signal transduction system in which receptor-stimulated activation of Ptdlns-dependent phospholipase C (PLC) leads to hydrolysis of phosphatidylinositol $(4,5)$ bisphosphate (Ptdlns $\left.(4,5) \mathrm{P}_{2}\right)$ to produce the two second messengers: inositol $(1,4,5)$ trisphosphate $\left(\operatorname{Ins}(1,4,5) \mathrm{P}_{3}\right)$, which acts to release $\mathrm{Ca}^{2+}$ from internal $\mathrm{Ca}^{2+}$ stores, and diacylglycerol, which activates protein kinase $\mathrm{C}$ (for a review, see Berridge, 1992). Mouse (Kane et al., 1992), rabbit (Fahy and Kane, 1993) and cattle (Hynes et al., 2000) embryos, and mouse embryonic stem (ES) cells (Duffy and Kane, 1996) incorporate inositol into the phosphoinositides and inositol phosphates of the Ptdlns signal transduction system. In addition, inhibitors of PLC inhibit mouse blastocyst formation (Stachecki and Armant, 1996). Perhaps the most important evidence for an essential role for phosphoinositide

*Correspondence

Email: michael.kane@nuigalway.ie compounds in preimplantation development is the demonstration that knocking out the PLC $\beta 3$ gene prevents development of mouse embryos to the blastocyst stage (Wang et al., 1998).

Another role for inositol is in the formation of glycosylphosphatidylinositol (GPI) lipids, which function as anchors for the attachment of surface proteins to the plasma membrane of various cell types (for a review, see Low, 1987). The GPI anchors typically contain phosphatidylinositol inserted in the cell membrane, connected to a carbohydrate core structure consisting of glucosamine, mannose, galactose and ethanolamine, to which the protein is attached by a phosphodiester linkage (for reviews, see Englund, 1993; McConville and Menon, 2000). Another characteristic of the GPI anchors is that they may be cleaved to release the protein by endogenous Ptdlns-specific phospholipases (Brewis et al., 1994).

Glycosylphosphatidylinositols are also involved in the signal transduction pathways of numerous hormones and growth factors such as insulin (Saltiel and Cuatrecasas, 1986), and growth factors and cytokines, including insulinlike growth factor I (IGF-I), epidermal growth factor (EGF), and transforming growth factor $\beta 1$ (TGF- $\beta 1$ ) as well as interleukins 1 and 2 (reviewed by Jones and Varela-Nieto, 1998). Insulin and other growth factors activate PLC to hydrolyse GPI, resulting in the release of the polar head group, an inositol-containing oligosaccharide called an 


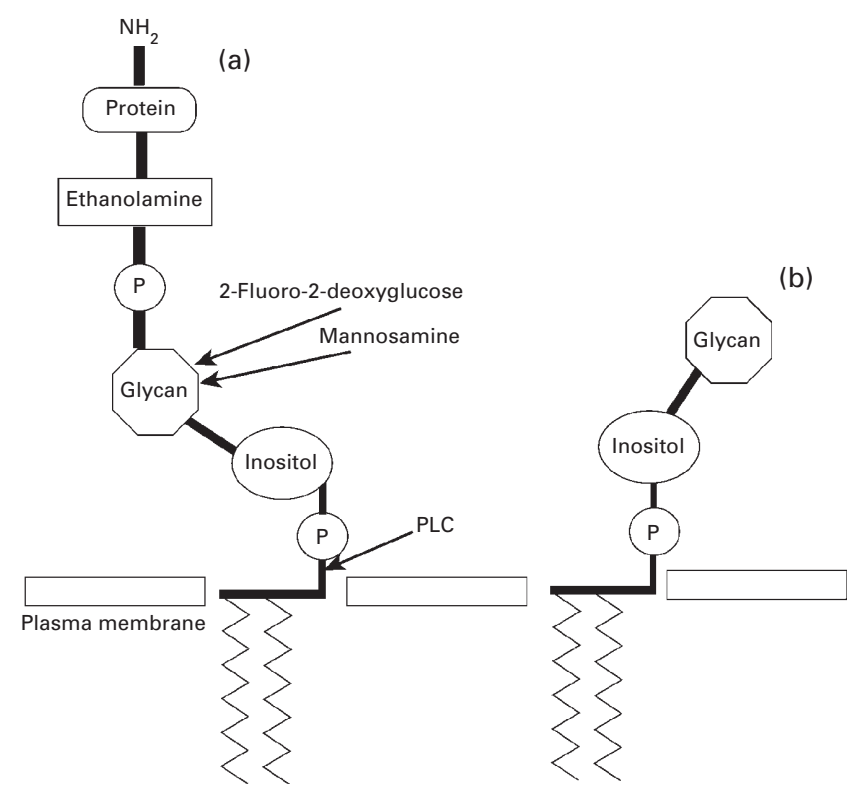

Fig. 1. Structural comparison between (a) glycosylphosphatidylinositol protein anchors and (b) glycosylphosphatidylinositols involved in signal transduction. The two lipid classes have a common phosphatidylinositol base. One difference between the two lipids is the presence of ethanolamine in the glycosylphosphatidylinositol (GPI) protein anchor and its absence in signalling GPI. Another difference is in the glycan structure. The glycan of GPI anchors most commonly consists of three mannose residues and glucosamine, whereas the glycan in the signalling GPI usually consists of galactose and glucosamine. The sites of action of phospholipase C (PLC) and the metabolic inhibitors 2-fluoro-2deoxyglucose and mannosamine are also shown. The mechanism of action of the metabolic inhibitors is to cause truncation of the glycan structure and thus, in the case of the protein anchor, prevent the addition of ethanolamine and the terminal protein, which is linked to the terminal ethanolamine. P: phosphate group. (Modified from Jones and Varela-Nieto, 1998.)

inositolphosphate glycan (IPG) (Saltiel, 1991; Jones and Varela-Nieto, 1998).

Labelling studies have shown that the IPG-forming GPI contains inositol and glucosamine (Saltiel et al., 1986) and galactose (Mato et al., 1987b). The GPI protein anchor appears to be very similar in structure to the IPG-forming GPI (Saltiel et al., 1986) but there appear to be a number of important differences, for example, the GPI anchor, but not the IPG-forming GPI, contains mannose in the carbohydrate core and ethanolamine at the terminal position (for reviews, see Saltiel, 1991; Jones and Varela-Nieto, 1998; Fig. 1).

There is tentative evidence to indicate the production of GPIs by both preimplantation embryos and ES cells. The presence of an inositol- and glucosamine-containing lipid (termed lipid X in this study) which migrated between Ptdlns and phosphatidylinositol 4-phosphate $(\operatorname{Ptd} \operatorname{lns}(4) \mathrm{P})$ in a thin layer chromatography (TLC) system was observed in studies on mouse (Kane et al., 1992) and rabbit blastocysts (Fahy and Kane, 1993), and on ES cells (Duffy and Kane, 1996).
This region between Ptdlns and PtdIns(4)P has been shown to contain the IPG-forming GPI (Saltiel and Cuatrecasas, 1986). There was also evidence in ES cells of the formation of a second glucosamine-containing lipid (called lipid $Y$ in this study) co-migrating with Ptdlns (Duffy and Kane, 1996). The aim of the present study was to investigate the identity of these two lipids in a mouse ES cell line.

\section{Materials and Methods}

\section{Embryonic stem cell culture}

Mouse ES cells of the CCE cell line were cultured in the standard culture medium for ES cells (Robertson, 1987) consisting of Dulbecco's modified Eagles medium (DMEM; GibcoBRL, Life Technologies Ltd, Paisley) in its 'high glucose' formulation (25 mmol glucose $\mathrm{I}^{-1}$ ) supplemented with 150 iu penicillin $\mathrm{G} \mathrm{ml}^{-1}, 150 \mu \mathrm{g}$ streptomycin sulfate $\mathrm{ml}^{-1}, 0.007 \mu \mathrm{g} \beta$-mercaptoethanol $\mathrm{ml}^{-1}, 1000$ iu mouse leukaemia inhibitory factor (LIF) $\mathrm{ml}^{-1}$, and $5 \%$ fetal calf serum (FCS). This standard culture medium was used routinely unless otherwise stated. Cells were grown on gelatinized tissue culture flasks and 24-well plates in an incubator maintained at $37^{\circ} \mathrm{C}$ in an atmosphere of $5 \% \mathrm{CO}_{2}$ in air. In all radiolabelling studies, the ES cells were first grown to $60 \%$ confluency in $25 \mathrm{~cm}^{2}$ flasks, and then the exponentially growing cells were trypsinized and seeded at $2 \times 10^{5}$ cells $^{-1}$ in 24-well plates in fresh standard DMEM and allowed to attach for $24 \mathrm{~h}$. After the $24 \mathrm{~h}$ attachment period, the radiolabels were added for a further $24 \mathrm{~h}$ unless otherwise stated. For labelling with $\left[2-{ }^{3} \mathrm{H}\right]$ inositol, cells were cultured in inositol-depleted DMEM (that is, standard DMEM minus inositol, although the medium is not truly inositol-free as small amounts of inositol are found in FCS) for the course of the labelling period. For labelling with $\left[1-{ }^{3} \mathrm{H}\right]$ ethan-1-ol-2-amine hydrochloride, D- $\left[2-{ }^{3} \mathrm{H}\right]$ mannose, D- $\left[2-{ }^{3} \mathrm{H}\right]$ galactose and $\mathrm{D}-\left[2-{ }^{3} \mathrm{H}\right]$ glucosamine hydrochloride, cells were cultured in low glucose $\left(5.56 \mathrm{mmol} \mathrm{I}^{-1}\right)$ DMEM for the course of the labelling period. Low glucose medium is essentially identical to the standard high glucose medium with the exception of the reduced glucose content. All radiolabels except inositol were obtained from Amersham International plc (Amersham); labelled inositol was obtained from both Amersham and NEN (Dupont).

\section{Phospholipid extraction, separation on TLC and autoradiography}

After labelling, the phospholipids were extracted as described by Roldan and Harrison (1989) except that perchloric acid was substituted for trichloroacetic acid throughout. An aliquot of the sample was taken after acid precipitation for protein determination, which was carried out using the microtitre protocol of the Pierce BCA protein assay (Pierce and Warriner, Chester). The extracted lipid was then separated by TLC on pre-coated silica-gel $60 \mathrm{~F}_{254}$ plates that were sprayed with $1 \%(\mathrm{w} / \mathrm{v})$ potassium oxalate before use and activated at $110^{\circ} \mathrm{C}$ for $1 \mathrm{~h}$. The solvent system 
used was chloroform-methanol-water-concentrated (25\%) $\mathrm{NH}_{3}$ solution $(45: 35: 8: 2, \mathrm{v} / \mathrm{v})$. Autoradiography was carried out using Hyperfilm- ${ }^{3} \mathrm{H}$ (Amersham International plc). The cassette was shielded from light and stored for 2-3 weeks at room temperature and the film then developed in an automatic X-ray processor. The film was used as a template, and areas corresponding to known phosphoinositides and all other areas showing the incorporation of radioactivity were scraped from the TLC plate and placed into scintillation vials. One millilitre of methanol was added to each vial and the samples were left overnight to elute the lipids from the silica. After addition of scintillation cocktail $(8 \mathrm{ml}$, Beckman Ready Value, Beckman Instruments, High Wycombe) to each vial, the vials were vortexed and counted in a scintillation counter. Incorporation was expressed as d.p.m. per $\mu$ g of protein.

Experiment 1: incorporation of $\left[{ }^{3} \mathrm{H}\right]$ inositol, $\left[{ }^{3} \mathrm{H}\right]$ ethanolamine, $\left[{ }^{3} \mathrm{H}\right]$ mannose, $\left[{ }^{3} \mathrm{H}\right]$ galactose and $\left[{ }^{3} \mathrm{H}\right]$ glucosamine into phosphoinositides

After the $24 \mathrm{~h}$ attachment period, the cells were cultured for a further $24 \mathrm{~h}$ in the presence of one of the following: $\left[{ }^{3} \mathrm{H}\right]$ inositol $\left(3 \mu \mathrm{Ci} \mathrm{ml}^{-1}\right),\left[{ }^{3} \mathrm{H}\right]$ glucosamine $\left(20 \mu \mathrm{Ci} \mathrm{ml}^{-1}\right)$, $\left[{ }^{3} \mathrm{H}\right]$ ethanolamine $\left.\left(20 \mu \mathrm{Ci} \mathrm{ml}^{-1}\right),{ }^{3} \mathrm{H}\right]$ mannose $\left(20 \mu \mathrm{Ci} \mathrm{ml}^{-1}\right)$ or [ ${ }^{3} \mathrm{H}$ ]galactose $\left(20 \mu \mathrm{Ci} \mathrm{ml}^{-1}\right)$. After removal of supernatant, the reactions were stopped with $0.5 \mathrm{ml}$ of $10 \%(\mathrm{w} / \mathrm{v})$ perchloric acid per culture well, the cells were scraped from the wells, lipids were extracted and the incorporation measured. Cells were also cultured in the presence of $\left[{ }^{3} \mathrm{H}\right]$ ethanolamine $\left(10 \mu \mathrm{Ci} \mathrm{ml}^{-1}\right)$ for different periods $(4,8$, 16 and $24 \mathrm{~h}$ ).

Experiment 2: effect of GPI synthesis inhibitors, mannosamine and 2-fluoro-2-deoxyglucose, on ethanolamine incorporation into phosphoinositides

After the $24 \mathrm{~h}$ attachment period, the medium was changed to low glucose DMEM and the inhibitors, mannosamine $\left(0.1,1.0\right.$ and $\left.10.0 \mathrm{mmol} \mathrm{I}^{-1}\right)$ and 2-fluoro-2deoxyglucose $\left(1,5\right.$ and $\left.10 \mu \mathrm{mol} \mathrm{I}^{-1}\right)$, were added. Two hours later, $\left[{ }^{3} \mathrm{H}\right]$ ethanolamine $\left(10 \mu \mathrm{Ci} \mathrm{ml}{ }^{-1}\right)$ was added. At the end of the $24 \mathrm{~h}$ treatment period, the reactions were stopped, lipids extracted and incorporation measured. Mannosamine and 2-fluoro-2-deoxyglucose were obtained from Sigma (Poole).

Experiment 3: effect of phospholipase C treatment on the amount of $\left.{ }^{3} \mathrm{H}\right]$ ethanolamine-labelled lipid $Y$ present in embryonic stem cell membranes

After the $24 \mathrm{~h}$ attachment period, the cells were cultured for a further $23 \mathrm{~h}$ in the presence of $\left[{ }^{3} \mathrm{H}\right]$ ethanolamine $(10$ $\mu \mathrm{Ci} \mathrm{ml}^{-1}$ ) in standard DMEM. At the end of the $23 \mathrm{~h}$ period, the medium was removed and $500 \mu$ l phospholipase C buffer was added for $1 \mathrm{~h}$ at $37^{\circ} \mathrm{C}$. The phospholipase $\mathrm{C}$ used was type III (Sigma) and is non-specific in that it hydrolyses phosphatidylcholine (PtdCho) and phosphatidylethanolamine
(PtdEtn) as well as Ptdlns. The phospholipase $\mathrm{C}$ buffer contained 10 iu phospholipase $\mathrm{C} \mathrm{ml}^{-1}$ in PBS with $10 \mathrm{mmol}$ EDTA $\mathrm{I}^{-1}$ and $0.1 \mathrm{mmol}$ sodium acetate $\mathrm{I}^{-1}$ (Low and Finean, 1977). At the end of the $24 \mathrm{~h}$ treatment period, the reactions were stopped, lipids extracted and incorporation measured. A control treatment without phospholipase $\mathrm{C}$ treatment was also carried out.

Experiment 4: effect of pretreatment with the GPI synthesis inhibitor, mannosamine, on the amount of $\left.{ }^{3} \mathrm{H}\right]$ ethanolamine-labelled GPI released by embryonic stem cells treated with phospholipase C

After the $24 \mathrm{~h}$ attachment period, the cells were cultured for a further $23 \mathrm{~h}$ in the presence of $\left[{ }^{3} \mathrm{H}\right]$ ethanolamine $\left(10 \mu \mathrm{Ci} \mathrm{m}{ }^{-1}\right)$ in low glucose DMEM to which $10 \mathrm{mmol}$ mannosamine $\mathrm{I}^{-1}$ was added $1 \mathrm{~h}$ before $\left[{ }^{3} \mathrm{H}\right]$ ethanolamine addition. At the end of the $23 \mathrm{~h}$ period, the medium was removed and $500 \mu \mathrm{l}$ phospholipase $\mathrm{C}$ buffer was added for $1 \mathrm{~h}$ at $37^{\circ} \mathrm{C}$. At the end of the $1 \mathrm{~h}$ incubation period, the buffer was removed and centrifuged at $1000 \mathrm{~g}$ for $5 \mathrm{~min}$ to remove cellular debris. The supernatant was placed in a scintillation vial, $8 \mathrm{ml}$ cocktail was added and the radioactivity was counted.

\section{Statistical analysis}

Data from all experiments were analysed by standard ANOVA techniques followed by a post hoc Dunnett's or Scheffe's $S$ test.

\section{Results}

Experiment 1: incorporation of $\left[{ }^{3} \mathrm{H}\right]$ inositol, $\left[{ }^{3} \mathrm{H}\right]$ ethanolamine, $\left[{ }^{3} \mathrm{H}\right]$ mannose, $\left[{ }^{3} \mathrm{H}\right]$ galactose and $\left.{ }^{3} \mathrm{H}\right]$ glucosamine into phosphoinositides

$\left[{ }^{3} \mathrm{H}\right]$ Inositol was incorporated into four main lipid spots (Fig. 2a). Three of these lipids were identified on the basis of their co-migration with cold lipid standards as Ptdlns, PtdIns(4)P and PtdIns(4,5) $\mathrm{P}_{2}$. The fourth lipid (labelled lipid $X$ in Fig. 2a), which consistently migrated between Ptdlns and Ptdlns(4)P, did not migrate with any known standard. However, inositol-containing lipids in this region have been reported to be members of the IPG-forming class of GPI glycolipids (Saltiel and Cuatrecasas, 1986; Saltiel et al., 1986).

$\left[{ }^{3} \mathrm{H}\right]$ Glucosamine was incorporated into two spots in the phosphoinositide region of the TLC plate (Fig. 2b, lane D): one spot that migrated between Ptdlns and Ptdlns(4)P in the region of the unidentified inositol-containing lipid (Fig. 2a, lipid X) and one spot (lipid Y) that co-migrated with Ptdlns.

$\left[{ }^{3} \mathrm{H}\right]$ Ethanolamine was incorporated into a number of spots. The major spot was identified as PtdEtn on the basis of its co-migration with unlabelled PtdEtn lipid standard. A second spot migrated in the region of the Ptdlns standard (Fig. 2b, lipid $\mathrm{Y}$ ) and the extent of labelling of this spot increased over time (Fig. 2b, lane A; Fig. 3). Ethanolamine 
(a)

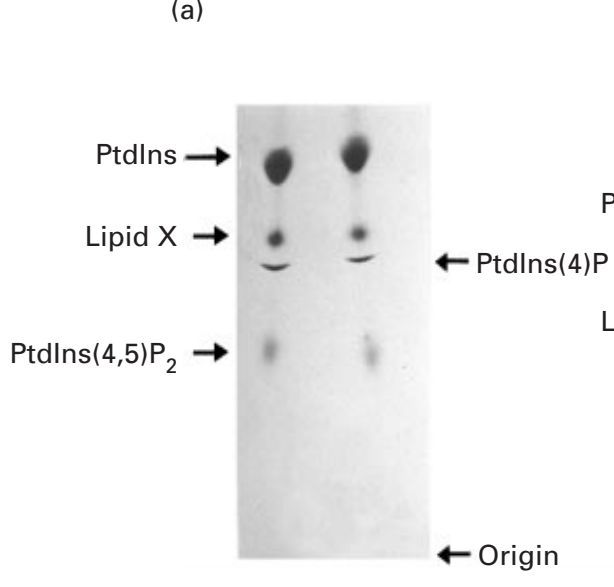

(b)

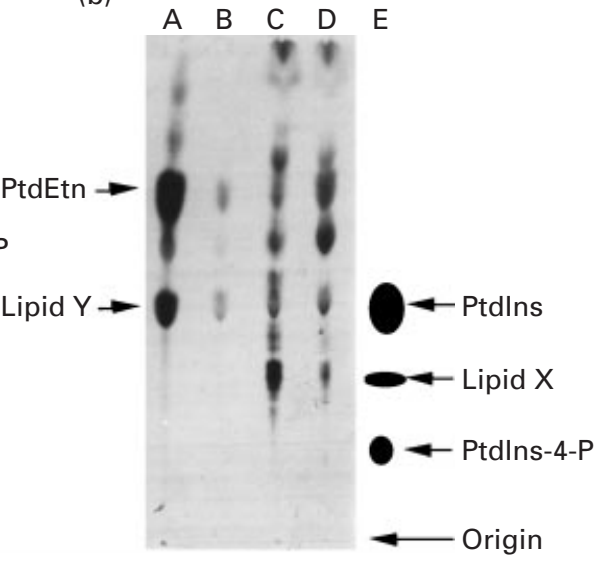

Fig. 2. Autoradiograms showing the TLC separation of phospholipids extracted from mouse embryonic stem cells labelled with radiolabelled phospholipid precursors for $24 \mathrm{~h}$. The autoradiograms shown are representative of all separations carried out $(n=4)$. (a) Cells incubated with $\left[{ }^{3} \mathrm{H}\right]$ inositol. Lipid identification in the case of the three phosphoinositides, PtdIns, PtdIns(4)P and PtdIns $(4,5) \mathrm{P}_{2}$, was on the basis of co-migration with unlabelled lipid standards visualized by iodine staining. (b) Cells incubated with $\left[{ }^{3} \mathrm{H}\right]$ ethanolamine $\mathrm{ml}^{-1}$ (lane A), $\left[{ }^{3} \mathrm{H}\right]$ mannose (lane B), $\left[{ }^{3} \mathrm{H}\right]$ galactose (lane $\mathrm{C}$ ) and $\left[{ }^{3} \mathrm{H}\right]$ glucosamine (lane D). Lane E shows the profile observed when unlabelled phosphoinositide standards were run on the same plate; the position of lipid $X$ was derived by interpolation from (a). Phosphatidylethanolamine (PtdEtn) was identified by co-migration with cold PtdEtn standard. Lipid Y co-migrated with cold Ptdlns standard.

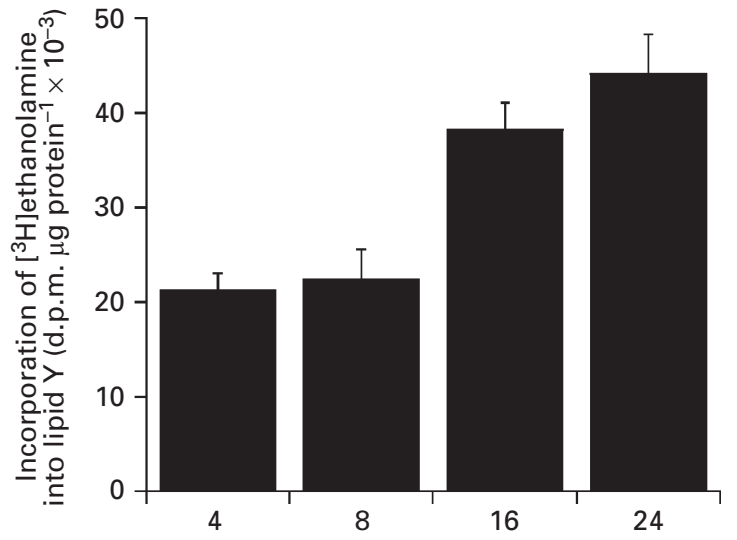

Duration of incubation with $\left[{ }^{3} \mathrm{H}\right]$ ethanolamine $(\mathrm{h})$

Fig. 3. Incorporation of $\left[{ }^{3} \mathrm{H}\right]$ ethanolamine into the putative glycosylphosphatidylinositol (GPI) anchor (lipid Y) over time. Incorporation increased linearly with time $(P<0.001)$. Values are means \pm SEM for eight replicates.

incorporation into the spot co-migrating with the putative IPG-forming GPI spot (Fig. 2a, lipid X) was not detected.

$\left[{ }^{3} \mathrm{H}\right]$ Mannose was incorporated into one spot in the phosphoinositide region of the TLC plate that co-migrated with unlabelled Ptdlns standard (Fig. 2b, lane B). Mannose incorporation into the spot co-migrating with the putative IPG-forming GPI spot (Fig. 2a, lipid X) was not detected.

$\left[{ }^{3} \mathrm{H}\right]$ Galactose was incorporated into a number of spots in the phosphoinositide region of the TLC plate (Fig. 2b, lane $C$ ); one of these spots was in the region of the putative IPG-forming GPI spot (lipid X) and one spot was in the region of the putative $\mathrm{GPI}$ anchor spot (Fig. 2b, lane C, lipid Y).

\section{Experiment 2: effect of the GPI synthesis inhibitors, mannosamine and 2-fluoro-2-deoxyglucose, on ethanolamine incorporation into phosphoinositides}

Mannosamine significantly $(P<0.001)$ inhibited the incorporation of $\left[{ }^{3} \mathrm{H}\right]$ ethanolamine into the putative GPI anchor (lipid Y) in a dose-dependent manner (Fig. 4a). Mannosamine $\left(10 \mathrm{mmol} \mathrm{I}^{-1}\right)$ inhibited ethanolamine incorporation by approximately $45 \%$. The effect of mannosamine was reversed when the standard high glucose DMEM was used as the treatment medium (data not shown).

Only the highest concentration of 2-fluoro-2-deoxyglucose $\left(10 \mu \mathrm{mol} \mathrm{I}^{-1}\right)$ significantly $(P<0.001)$ inhibited ethanolamine incorporation; the magnitude of the inhibition was approximately 35\% (Fig. 4b). The specificity of this effect was shown by the finding that 2-fluoro-2-deoxyglucose had no effect at any concentration tested when standard high glucose DMEM medium was used (data not shown).

Experiment 3: effect of phospholipase $C$ treatment on the amount of ${ }^{3} \mathrm{H}$ ] ethanolamine-labelled lipid $Y$ present in embryonic stem cell membranes

Phospholipase C treatment resulted in a substantial 
(a)

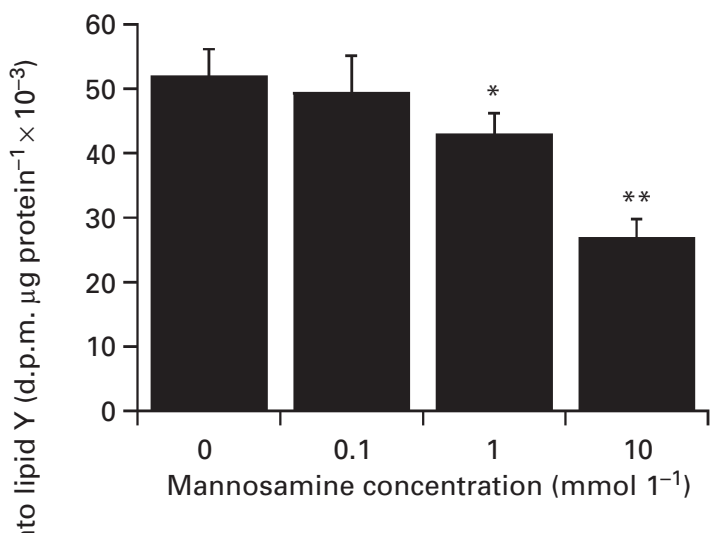

(b)

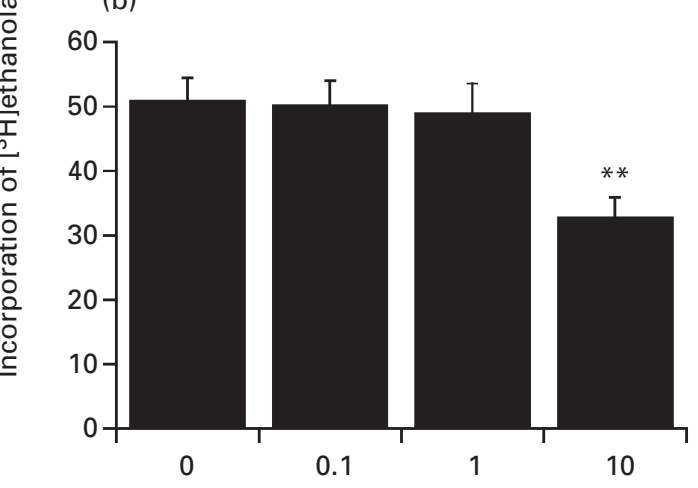

2-Fluoro-2-deoxyglucose concentration $\left(\mu \mathrm{mol} 1^{-1}\right)$

Fig. 4. Effect of inhibitors of glycosylphosphatidylinositol (GPI) formation on incorporation of $\left[{ }^{3} \mathrm{H}\right]$ ethanolamine into the putative GPI anchor (lipid Y). Values are means \pm SEM for eight replicates. (a) Mannosamine, (b) 2-Fluoro-2-deoxyglucose. Significantly different from control without inhibitor: ${ }^{*} P<0.01$; ${ }^{* *} P<0.001$.

decrease $(P<0.001)$ in the content of $\left[{ }^{3} \mathrm{H}\right]$ ethanolamine label in both the PtdEtn and the putative GPI anchor spot (lipid Y) from ES cell membranes (Fig. 5).

\section{Experiment 4: effect of pretreatment with the GPI} synthesis inhibitor, mannosamine, on the amount of $\left.{ }^{3} \mathrm{H}\right]$ ethanolamine-labelled GPI released by embryonic stem cells treated with phospholipase $C$

In the absence of phospholipase $\mathrm{C}$ activity, a limited amount of $\left[{ }^{3} \mathrm{H}\right]$ ethanolamine was released into the surrounding medium (Fig. 6); this release was slightly but significantly $(P<0.001)$ decreased by preincubation with mannosamine. Phospholipase $C$ treatment resulted in an approximately fourfold increase in the amount of ethanolamine-labelled components released into the medium. Preincubation with mannosamine almost totally abolished this release. (b)

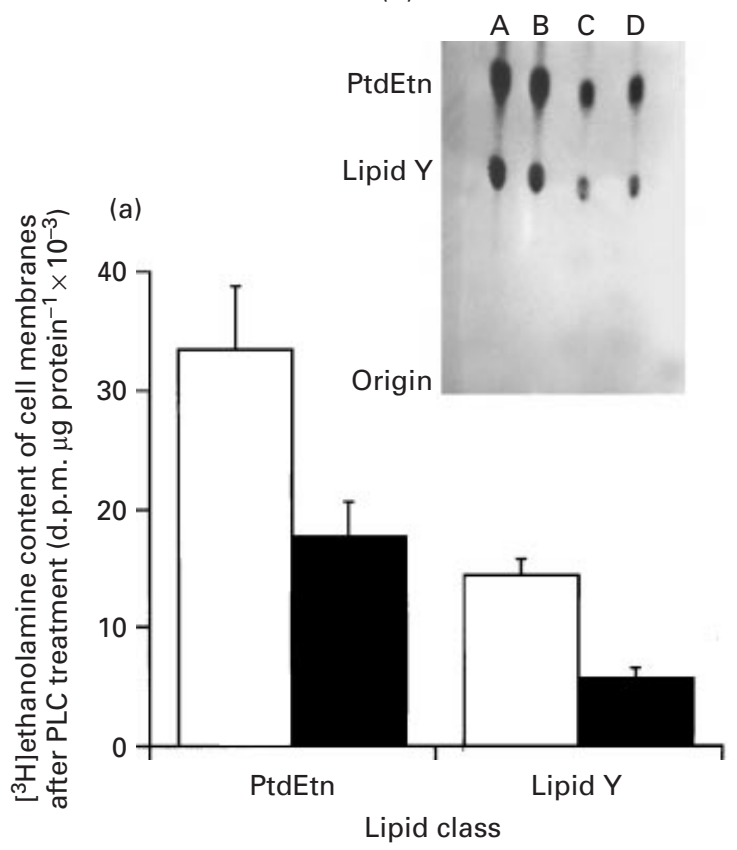

Fig. 5. Effects of treating intact mouse embryonic stem (ES) cells with phospholipase $\mathrm{C}(\mathrm{PLC})$ on the amount of $\left[{ }^{3} \mathrm{H}\right]$ ethanolaminelabelled putative glycosylphosphatidylinositol (GPI) anchor present in ES cell membranes. (a) Label remaining in phosphatidylethanolamine (PtdEtn) and GPI spots after PLC treatment. $\square$ : Control without PLC treatment; $\mathbf{\square}$ : PLC treated. Values are means \pm SEM for eight replicates. PLC significantly $(P<0.001)$ decreased the amount of label in both the PtdEtn and putative GPI anchor (lipid Y) spots. (b) Autoradiogram representative of all separations carried out $(n=8)$. Lanes A and B: control ES cells not treated with PLC; lanes C and D: cells treated with PLC.

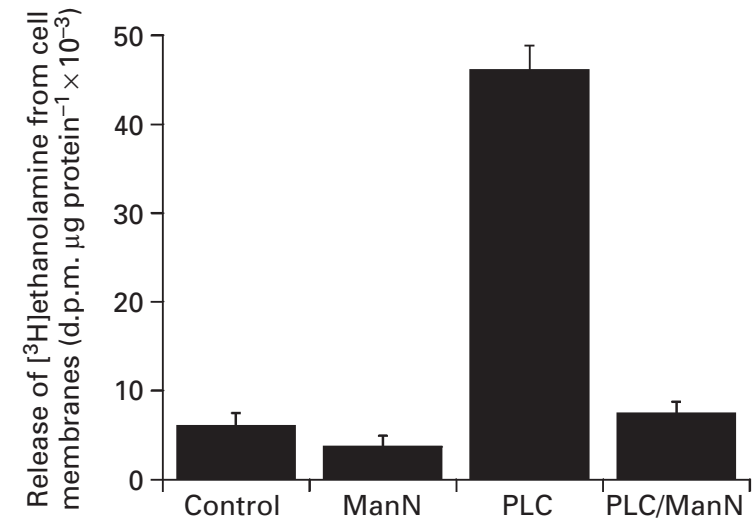

Fig. 6. Effect of mannosamine (ManN, $10 \mathrm{mmol} \mathrm{I}^{-1}$ ) pre-treatment on phospholipase $\mathrm{C}$ ( $\mathrm{PLC})$-mediated release of $\left[{ }^{3} \mathrm{H}\right]$ ethanolamine label from mouse embryonic stem (ES) cells. Values are means \pm SEM for eight replicates. Mannosamine decreased the amount of label released from ES cells both in the presence $(P<0.001)$ and absence $(P<0.05)$ of PLC treatment. 


\section{Discussion}

Previous work using inositol labelling of an ES cell line followed by TLC indicated the presence of the three standard inositol-containing lipids, Ptdlns, Ptdlns(4)P and Ptdlns $(4,5) \mathrm{P}_{2}$, as well as a fourth lipid that migrated between Ptdlns and Ptdlns(4)P (Duffy and Kane, 1996). This unidentified lipid, which has been named lipid X, was also shown to incorporate glucosamine. There was also evidence of another spot labelled with glucosamine that comigrated with PtdIns, which has been named lipid Y. The present study confirmed that inositol is incorporated into phosphoinositides and that glucosamine is incorporated into two putative glycosylphosphatidylinositols, lipid $X$ and lipid $Y$. On the basis of other studies, lipid $X$ and lipid $Y$ could be members of either the GPI class of protein anchors (Low, 1987) or the IPG-forming GPI class involved in signal transduction (Saltiel and Cuatrecasas, 1986; Jones and Varela-Nieto, 1998).

A commonly accepted defining difference between the two GPI glycolipid classes is that the GPI protein anchors contain ethanolamine, whereas the IPG-forming GPIs do not (Mato et al., 1987a; Saltiel, 1991; Suzuki et al., 1991; Jones and Varela-Nieto, 1998). However, there has been one report of ethanolamine being incorporated into insulinsensitive IPG-forming GPI (Kajiyoshi, 2000). There is also evidence that the GPI protein anchors contain galactose and mannose, whereas the IPG-forming GPI also contains galactose but not usually mannose (Mato et al., 1987b; Suzuki et al., 1991). Therefore, in the present study, ethanolamine, mannose and galactose labelling were used in an effort to identify the lipid classes to which lipids $X$ and $Y$ belong. Lipid $X$ was not labelled with ethanolamine or mannose but was labelled with inositol, glucosamine and galactose, indicating strongly that lipid $\mathrm{X}$ is a member of the IPG-forming class of GPI. Definitive proof that this lipid is an IPG-forming GPI would be the demonstration that the polar head-group breakdown product of the phospholipase $\mathrm{C}$ treatment of the parent lipid stimulated enzymes such as cAMP phosphodiesterase and adenylate cyclase. In cellfree studies, the insulin-stimulated IPG has been shown to regulate the activity of a number of enzymes associated with the response to insulin (Frick et al., 1998), including cAMP phosphodiesterase (Saltiel et al., 1986), cAMPdependent protein kinase (Villalba et al., 1988) and adenylate cyclase (Saltiel, 1987).

Lipid Y was labelled with inositol, glucosamine, ethanolamine, galactose and, to a limited extent, with mannose. Incorporation of mannose may have been limited as a result of its use for energy production because of the low glucose content of the medium used. The ability of inhibitors of GPI anchor biosynthesis to inhibit ethanolamine incorporation into lipid $\mathrm{Y}$ was examined to determine whether lipid $Y$ is a GPI anchor. Mannosamine and 2flouro-2-deoxyglucose significantly inhibited ethanolamine incorporation into this lipid. The biosynthesis of GPI anchors involves the formation of nonacetylated-glucosamine- phosphatidylinositol and the sequential addition of mannose residues to complete the glycan core structure (McConville and Menon, 2000). The mannose residues are transferred from dolichyl-phosphate-mannose (Dol-P-Man), which is synthesized by the enzyme Dol-P-Man synthase (McConville and Menon, 2000). One proposed mechanism of action for mannosamine is that it becomes inserted into the glycan core structure and prevents the addition of further mannose residues and subsequently prevents the addition of ethanolamine residues (Lisanti et al., 1991). Another mechanism suggested is the inhibition of glycosyltransferases (Field et al., 1993). The mechanism of action of 2-fluoro-2-deoxyglucose in inhibiting GPI synthesis is that it inhibits the formation of Dol-P-Man, resulting in the formation of truncated oligosaccharides and the subsequent inhibition of ethanolamine incorporation into the GPI anchor (Takami et al., 1992).

The fact that both mannosamine and 2-fluoro-2-deoxyglucose inhibit ethanolamine incorporation into lipid $Y$ provides further evidence that this lipid is a GPI anchor, and is consistent with the results observed in previous metabolic labelling studies. As high glucose concentrations are known to reverse the inhibitory effect of mannosamine (Pan and Elbein, 1985), the abolition of the inhibitory effect of mannosamine by a high glucose concentration provides evidence that the effect of mannosamine is not a nonspecific toxic effect.

Whole cells were treated with phospholipase $\mathrm{C}$, which hydrolyses GPI anchors (Low and Finean, 1977), to further characterize the lipids. Treatment of cells pre-labelled with ethanolamine resulted in the release of label into the surrounding medium. As the phospholipase $\mathrm{C}$ preparation used is not specific to Ptdlns but can also act on PtdCho and PtdEtn, some of this label was released from PtdEtn. However, treatment with phospholipase $\mathrm{C}$ decreased the amount of ethanolamine label in the putative GPI anchor spot (lipid Y) and the total amount of ethanolamine label released was decreased markedly by pretreatment of the cells with mannosamine, indicating that much of the label was released from the putative GPI anchor. Since mannosamine inhibition is known to act on GPI anchor formation but not on phosphatidylethanolamine formation, this finding is consistent with the view that these lipids are GPI anchors.

This study demonstrates the presence of GPI protein anchors in a mouse ES cell line and also provides strong evidence that IPG-forming GPIs are also present. As ES cells closely resemble inner cell mass cells of the early embryo, and TLC of phospholipid extracts of $\left[{ }^{3} \mathrm{H}\right]$ inositol-labelled mouse and rabbit blastocysts reveals the presence of similar lipids in these embryos (Kane et al., 1992; Fahy and Kane, 1993), it is probable that glycosylphosphatidylinositols of both the IPG-forming and the anchor type have a role in blastocyst formation. Glycosylphosphatidylinositols of the IPG-forming type may also be involved in mediating the actions of growth factors of autocrine or paracrine origin. 2-Deoxyglucose inhibits mouse and rabbit blastocyst 
formation, even in the presence of energy substrates and amino acids, and it is possible that the formation of glycosylphosphatidylinositols is one of the sites at which the inhibitory effect of 2-deoxyglucose is exerted.

This work was funded by research grants from the Irish Health Research Board to M. T. Kane and from the National University of Ireland, Galway Millennium Fund to L. R. Quinlan. The authors thank E. Notarianni, formerly of the Department of Genetics, Cambridge University, for a gift of the embryonic stem cells.

\section{References}

Berridge MJ (1992) Phosphoinositides and cell signaling Fidia Research Foundation Neuroscience Award Lectures 6 5-45

Brewis IA, Turner AJ and Hooper NM (1994) Activation of the glycosylphosphatidylinositol-anchored membrane dipeptidase upon release from pig kidney membranes by phospholipase C Biochemical Journal 303 633-638

Duffy C and Kane MT (1996) Investigation of the role of inositol and the phosphatidylinositol signal transduction system in mouse embryonic stem cells Journal of Reproduction and Fertility 108 87-93

Englund PT (1993) The structure and biosynthesis of glycosyl phosphatidylinositol protein anchors Annual Review of Biochemistry 62 121-138

Fahy MM and Kane MT (1992) Inositol stimulates DNA and protein synthesis, and expansion by rabbit blastocysts in vitro. Human Reproduction 7 550-552

Fahy MM and Kane MT (1993) Incorporation of $\left[{ }^{3} \mathrm{H}\right]$ inositol into phosphoinositides and inositol phosphates by rabbit blastocysts Molecular Reproduction and Development 34 391-395

Field MC, Medina-Acosta E and Cross GA (1993) Inhibition of glycosylphosphatidylinositol biosynthesis in Leishmania mexicana by mannosamine Journal of Biological Chemistry 268 9570-9577

Frick W, Bauer A, Bauer J, Wied S and Müller G (1998) Structure-activity relationship of synthetic phosphoinositolglycans mimicking metabolic insulin action Biochemistry 3713 421-13 436

Hynes AC, Sreenan JM and Kane MT (2000) Uptake and incorporation of myo-inositol by bovine preimplantation embryos from two-cell to early blastocyst stages Molecular Reproduction and Development $\mathbf{5 5}$ 265-269

Jones DR and Varela-Nieto (1998) The role of glycosyl-phosphatidylinositol in signal transduction International Journal of Biochemistry and Cell Biology $30313-326$

Kajiyoshi M (2000) Incorporation of ethanolamine into insulin-sensitive glycosylated phosphatidylinositol of chick embryo fibroblasts Biochimica et Biophysica Acta 1488 255-267

Kane MT and Bavister BD (1988) Vitamin requirements for development of eight-cell hamster embryos to hatching blastocysts in vitro. Biology of Reproduction 39 1137-1143

Kane MT, Norris M and Harrison RAP (1992) Uptake and incorporation of inositol by preimplantation mouse embryos Journal of Reproduction and Fertility 96 617-625

Lisanti MP, Field MC, Caras IW, Menon AK and Rodriguez-Boulan E (1991) Mannosamine, a novel inhibitor of glycosyl-phosphatidylinositol incorporation into proteins EMBO Journal 10 1969-1977
Low MG (1987) Biochemistry of the glycosyl-phosphatidylinositol membrane protein anchors Biochemical Journal 244 1-13

Low MG and Finean JB (1977) Release of alkaline phosphatase from membranes by a phosphatidylinositol-specific phospholipase C Biochemical Journal 167 281-284

McConville MJ and Menon AK (2000) Recent developments in the cell biology and biochemistry of glycosylphosphatidylinositol lipids Molecular Membrane Biology 17 1-16

Mato JM, Kelly KL, Abler A and Jarett L (1987a) Identification of a novel insulin-sensitive glycophospholipid from $\mathrm{H} 35$ hepatoma cells Journal of Biological Chemistry 262 2131-2137

Mato JM, Kelly KL, Abler A, Jarett L, Corkey BE, Cashel JA and Zopf D (1987b) Partial structure of an insulin-sensitive glycophospholipid Biochemical and Biophysical Research Communications 146 764-770

Pan YT and Elbein AD (1985) The effect of mannosamine on the formation of lipid-linked oligosaccharides and glycoproteins in canine kidney cells Archives of Biochemistry and Biophysics 24 447-456

Robertson EJ (1987) Teratocarcinomas and Embryonic Stem Cells: A Practical Approach IRL Press, Oxford

Roldan ERS and Harrison RAP (1989) Polyphosphoinositide breakdown and subsequent exocytosis in the $\mathrm{Ca}^{2+} /$ ionophore-induced acrosome reaction of mammalian spermatozoa Biochemical Journal 259 397-406

Saltiel AR (1987) Insulin generates an enzyme modulator from hepatic plasma membranes: regulation of adenosine 3',5'-monophosphate phosphodiesterase, pyruvate dehydrogenase, and adenylate cyclase Endocrinology 120 967-972

Saltiel AR (1991) The role of glycosyl-phosphoinositides in hormone action Journal of Bioenergetics and Biomembranes 23 29-41

Saltiel AR and Cuatrecasas P (1986) Insulin stimulates the generation from hepatic membranes of modulators derived from an inositol glycolipid Proceedings National Academy of Sciences USA 83 5793-5797

Saltiel AR, Fox JA, Sherline P and Cuatrecasas P (1986) Insulin-stimulated hydrolysis of a novel glycolipid generates modulators of CAMP phosphodiesterase Science 233 967-972

Stachecki JJ and Armant DR (1996) Regulation of blastocoele formation by intracellular calcium release is mediated through a phospholipase Cdependent pathway in mice Biology of Reproduction 55 1292-1298

Suzuki S, Sugawara K, Satoh Y and Toyota T (1991) Insulin stimulates the generation of two putative insulin mediators, inositol-glycan and diacylglycerol in BC3H-1 myocytes Journal of Biological Chemistry 266 $8115-8121$

Takami N, Oda K and Ikehara Y (1992) Aberrant processing of alkaline phosphatase precursor caused by blocking the synthesis of glycosylphosphatidylinositol Journal of Biological Chemistry 267 1042-1047

Villalba M, Kelly KL and Mato JM (1988) Inhibition of cyclic AMPdependent protein kinase by the polar head group of an insulin-sensitive glycophospholipid Biochimica et Biophysica Acta 968 69-76

Wang S, Gebre-Medhin S, Betsholtz C, Stålberg P, Zhou YH, Larsson C, Weber G, Feinstein R, Öberg K, Gobl A and Skogseid B (1998) Targeted disruption of the mouse phospholipase $C \beta 3$ gene results in early embryonic lethality FEBS Letters 441 261-265

Received 23 April 2001.

First decision 8 June 2001.

Accepted 26 July 2001. 